\title{
SAINT LOUIS ENCEPHALITIS VIRUS IN MATO GROSSO, CENTRAL-WESTERN BRAZIL
}

\author{
Letícia Borges da Silva HEINEN(1), Nayara ZUCHI(1), Otacília Pereira SERRA(1), Belgath Fernandes CARDOSO(1), \\ Breno Herman Ferreira GONDIM(2), Marcelo Adriano Mendes dos SANTOS(3), Francisco José Dutra SOUTO(1), \\ Daphine Ariadne Jesus de PAULA(1), Valéria DUTRA(1) \& Renata DEZENGRINI-SLHESSARENKO(1)
}

\begin{abstract}
SUMMARY
The dengue virus (DENV), which is frequently involved in large epidemics, and the yellow fever virus (YFV), which is responsible for sporadic sylvatic outbreaks, are considered the most important flaviviruses circulating in Brazil. Because of that, laboratorial diagnosis of acute undifferentiated febrile illness during epidemic periods is frequently directed towards these viruses, which may eventually hinder the detection of other circulating flaviviruses, including the Saint Louis encephalitis virus (SLEV), which is widely dispersed across the Americas. The aim of this study was to conduct a molecular investigation of 11 flaviviruses using 604 serum samples obtained from patients during a large dengue fever outbreak in the state of Mato Grosso (MT) between 2011 and 2012. Simultaneously, 3,433 female Culex spp. collected with Nasci aspirators in the city of Cuiabá, MT, in 2013, and allocated to 409 pools containing 1-10 mosquitoes, were also tested by multiplex semi-nested reverse transcription PCR for the same flaviviruses. SLEV was detected in three patients co-infected with DENV-4 from the cities of Cuiabá and Várzea Grande. One of them was a triple coinfection with DENV-1. None of them mentioned recent travel or access to sylvatic/rural regions, indicating that transmission might have occurred within the metropolitan area. Regarding mosquito samples, one pool containing one Culex quinquefasciatus female was positive for SLEV, with a minimum infection rate (MIR) of 0.29 per 1000 specimens of this species. Phylogenetic analysis indicates both human and mosquito SLEV cluster, with isolates from genotype V-A obtained from animals in the Amazon region, in the state of Pará. This is the first report of SLEV molecular identification in MT.
\end{abstract}

KEYWORDS: Arbovirus; Molecular epidemiology; SLEV; Dengue virus; DENV; Virological surveillance; Tropical diseases.

\section{INTRODUCTION}

Saint Louis encephalitis virus (SLEV) is a recognized human pathogen classified in the Japanese encephalitis virus complex, Flavivirus genus, Flaviviridae family, circulating in the Americas. SLEV is an arbovirus maintained by zoonotic cycles involving Culex (Cx.) spp. and other mosquitoes as vectors; birds as amplifiers; humans and other animals as accidental final hosts ${ }^{7}$. Most human infections are subclinical. Some are unspecific acute febrile infections rarely accompanied by meningoencephalitis with increased severity and fatality in the elderly ${ }^{24}$.

SLEV is widely dispersed throughout the New World, from Canada to Argentina. However, clinical infection has become more frequent in the United States of America (USA) and, to a lesser extent, in Central and South America ${ }^{25}$. The virus was first reported during a human encephalitis outbreak in Saint Louis, USA, in $1933^{26}$. SLEV was first identified in Brazil in the 1960's in Sabethes belisarioi pools from the state of Pará (PA), in the northern region of the country ${ }^{16,24}$. Later, between 1967 and 1969 , it was detected in sentinel mice, sylvatic rodents and birds in the state of São Paulo (SP) ${ }^{8}$.
Reports of human infection in Brazil are scarce. The first report of human infection in Brazil was evidenced in Pará, in $1970^{16}$. In the 1990's, detection of anti-SLEV antibodies, including seroconversion, was reported in residents of an ecological reserve in Vale do Ribeira, $\mathrm{SP}^{19}$. A few human cases have been reported more recently: in a woman from the city of São Paulo, SP, $2004^{18}$ and in 20 patients from São José do Rio Preto (SP), two years later ${ }^{12,13,23}$. One case was identified in a suspected dengue fever patient from Ribeirão Preto (SP) in 20149. SLEV infection might not be rare in humans, but instead is often mistaken with dengue virus (DENV) and goes largely undiagnosed in Brazil.

Serological studies to estimate SLEV prevalence in the population of Central Brazil are limited in number. Often, antigenic similarity between DENV, SLEV and other flaviviruses compromises seroprevalence studies due to cross-reactions. A few reports indicate 5\% seroprevalence in northern and southeastern Brazil ${ }^{20}$. Seroprevalence studies with SLEV demonstrate that prevalence ranges from $3-43 \%$ within the Brazilian population ${ }^{9}$. Acute clinical infections are rarely reported in Brazil, possibly because humans are accidental or final hosts, and infections are frequently mild or unapparent, accompanied by transient low-titer

(1) Programa de Pós-Graduação em Ciências da Saúde, Faculdade de Medicina, Universidade Federal de Mato Grosso (FM/UFMT), Cuiabá, Mato Grosso, Brazil.

(2) Curso de Graduação em Medicina, Faculdade de Medicina, Universidade Federal de Mato Grosso (FM/UFMT), Cuiabá, Mato Grosso, Brazil.

(3) Laboratório Central de Saúde Pública do Mato Grosso, MT-Laboratório, Secretaria Estadual de Saúde, Cuiabá, Mato Grosso, Brazil.

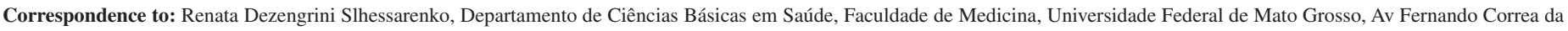
Costa 2367, CCBS-I, sala 82, 78060-900 Cuiabá, Mato Grosso, Brasil. Tel: +55-65-9213-7333; Fax: +55-65-3615-8863. E-mail: renatadezengrini@ yahoo.com.br 
HEINEN, L.B.S.; ZUCHI, N.; SERRA, O.P.; CARDOSO, B.F.; GONDIM, B.H.F.; SANTOS, M.A.M.; SOUTO, F.J.D.; PAULA, D.A.J.; DUTRA, V. \& DEZENGRINI-SLHESSARENKO, R. - Saint Louis encephalitis virus in Mato Grosso, Central-Western Brazil. Rev. Inst. Med. Trop. Sao Paulo, 57(3): 215-20, 2015.

viremia, and because routine differential diagnosis is not available ${ }^{12}$. Despite these difficulties, molecular approaches are important tools for population screening and the monitoring of flaviviruses ${ }^{12}$.

Among domestic animals, serologic evidence of SLEV circulation in horses has been reported in different states across Brazil, including Minas Gerais (MG), Rio de Janeiro (RJ), Mato Grosso do Sul (MS), Paraíba (PB), São Paulo (SP) and Pará (PA) ${ }^{15,17,20,21}$. Infected horses rarely develop clinical symptoms. However, one fatal neurological case of SLEV in a horse was recently described in $\mathrm{MG}^{20}$. Detection of SLEV in birds and serological evidence in horses from the state of Mato Grosso (MT) has also been reported ${ }^{14,18}$. Concerning vector species, SLEV is frequently identified in arthropods in the Amazon ${ }^{18}$ and other regions of the country. In 1993, SLEV was identified in Anopheles triannulatus and Culex spp. in northwestern São Paulo ${ }^{19}$. Usually, mosquito species serving as SLEV vectors vary according to geographical region. $C x$. pipiens, $C x$. quinquefasciatus and $C x$. negripalpus are the most frequently involved in SLEV transmission in the Americas. The virus persists in Culex spp. and these mosquitoes have been thought of responsible for SLEV maintenance between seasons ${ }^{10}$.

DENV is the most common flavivirus worldwide, representing an important health public problem. Reports of dengue fever outbreaks are frequent in Brazil. During epidemics, laboratory diagnosis of nonspecific acute febrile illnesses has been directed towards this flavivirus infection, hindering the detection of other arboviruses. The aim of this study was to investigate, using molecular approaches, other flaviviruses possibly circulating in MT.

\section{MATERIALS AND METHODS}

Human and arthropod sampling: After receiving approval from the institutional Ethics Committee (CEP/HUJM/100/2011), serum samples and epidemiological data were obtained from 604 patients in 20 cities across MT who sought medical care between October, 2011 and July, 2012 for acute febrile illnesses lasting less than five days. Also, 3,433 female Culex spp. were captured with Nasci aspirators from 184 censitary sectors of Cuiabá between January and May, 2013, identified using GPS locators. Three places were sampled at each sector. These Culicidae were identified according to dichotomy keys ${ }^{3,4}$ and a nested-PCR for Culex quinquefasciatus ${ }^{22}$ and allocated to 409 pools of between one and ten mosquitoes; 403 with 3,425 Cx. quinquefasciatus, five with seven $C x$. bidens or $C x$. interfor and one with one female of Culex spinosus.

Flaviviruses detection: Viral RNA from patient serum and total RNA from mosquito pools were extracted according to manufacturers' instructions (QIAamp Viral RNA Mini Kit, Qiagen and Trizol, Invitrogen, respectively). Extracted RNA was subject to a multiplex semi-nested reverse transcription PCR (RT-PCR) for a nucleotide region of flaviviruses NS5 gene (958 bp), followed by a species-specific secondary reaction differentiating 11 flaviviruses, as previously described ${ }^{1}$. Flaviviruspositive samples were confirmed by at least two independent single reactions with the same forward and species-specific reverse primer. PCR products were then submitted to nucleotide sequencing (3500 Genetic Analyzer, Applied Biossystems, USA). RNA from the SLEV strain genotype V-B BeH 355964 and no template were included as controls in all the reactions. Nucleotide sequences obtained from the positive control were analyzed to exclude contamination.
The minimum infection rate (MIR) was calculated with the formula ([number of positive pools / total specimens tested] x 1000), considering the total of Culex quinquefasciatus specimens tested (3,433 mosquitoes). SLEV-positive samples were subjected to inoculation in C6/36 cells ${ }^{16}$.

Nucleotide and amino acid sequence analysis of an envelope gene region from SLEV: A region of the SLEV envelope gene (477 bp) was amplified in positive samples via semi-nested RT - PCR and sequenced for phylogenetic analysis ${ }^{6}$. A phylogenetic tree was constructed with the neighbor-joining method, based on the Tamura-Nei distance model and 1,000 bootstrap replicates (Geneious R7 7.1.7, USA) using reference SLEV sequences from the GenBank database (PubMed, NCBI, USA). Deduced amino acid sequences were also analyzed (Geneious R7 version 7.1.7; Molecular Evolutionary Genetics Analysis version 5.05, USA), including residues present at specific positions characteristic of SLEV lineages ${ }^{10}$.

Nucleotide sequences obtained in this study were deposited at GenBank, pubMed (accession numbers: KJ699354; KJ957827; KJ847419; KJ801827).

\section{RESULTS}

Clinical and epidemiological findings: During this transversal observational study, three patients from the metropolitan area of Cuiabá who tested positive for DENV without neurological or hemorrhagic manifestations were also positive for SLEV. The first patient, a 47-yearold woman working in general services, sought medical care at a local hospital in May, 2012 with hyperthermia and posterior neck pain. She was also positive for DENV-1 and DENV-4 by RT-PCR, constituting a triple co-infection. DENV-4 was isolated from the serum of this patient.

The second patient, a 55-year-old male civil engineer, was treated at the same hospital on the same day for hyperthermia, headache, emesis and epigastric pain. The third patient was a 10-year-old male school pupil who sought medical care in the city of Várzea Grande in March 2012. Though clinical information was not available in his case, both patients were also positive for DENV-4 by RT-PCR.

All patients were urban residents without history of traveling or visits to sylvatic or rural areas. None of the patients reported previous cases of a similar disease. Attempts to recover SLEV from the co-infected serum were unsuccessful.

One pool containing a single $C x$. quinquefasciatus female was positive for SLEV in the metropolitan area of Cuiabá, with a MIR of 0.29 per 1000 specimens of this species.

The vast majority of the patients included in this study were positive for DENV serotypes (331/604 patients, 54.8\%) and were admitted during an epidemic coinciding with the introduction of the DENV-4 serotype in MT. The hyperendemicity of the four serotypes in Cuiabá, MT, nine co-infections between DENV-1/DENV-4 and one between DENV-2/ DENV-4 are going to be discussed separately.

Analysis of a partial sequence of the envelope gene: Phylogenetic analysis of an envelope glycoprotein gene region with $477 \mathrm{bp}$ showed that SLEV identified in a female $C x$. quinquefasciatus mosquito (SLEV_BR/ 
HEINEN, L.B.S.; ZUCHI, N.; SERRA, O.P.; CARDOSO, B.F.; GONDIM, B.H.F.; SANTOS, M.A.M.; SOUTO, F.J.D.; PAULA, D.A.J.; DUTRA, V. \& DEZENGRINI-SLHESSARENKO, R. - Saint Louis encephalitis virus in Mato Grosso, Central-Western Brazil. Rev. Inst. Med. Trop. Sao Paulo, 57(3): 215-20, 2015.

MT-CbaAr499/2013) and in human (SLEV_BR/MT-CbaH364/2012) samples in the present study belong to genotype $\mathrm{V}-\mathrm{A}$.

Envelope amino acid sequences from SLEV genotypes II, V and VIII retrieved from GenBank were compared with the human SLEV_BR/ MT-CbaH364/2012 and the mosquito SLEV_BR/MT-CbaAr499/2013 amino acid sequences. Variations in amino acid residues previously described as specific for strains belonging to lineages II, V and VIII were not present in the partial envelope gene sequence obtained here ${ }^{10}$. None of the variations described for other lineages in positions present in the partial envelope amino acid sequences analyzed were observed in the MT samples. A high homology was observed between the partial envelope amino acid sequences obtained from the female $C x$ sp. SLEV_BR/ MT-CbaAr499/2013 and the human SLEV_BR/MT-CbaH364/2012. However, the human SLEV_BR/MT-CbaH364/2012 presented a leucine residue at the position 96 , whereas all the other amino acid sequences from genotypes II, V and VII presented a proline residue. The SLEV_BR/ MT-CbaAr499/2013 obtained from mosquito exhibited an amino acid substitution for asparagine at position 45, whereas all the other SLEV strains in this study, including the human SLEV_BR/MT-CbaH364/2012, have a lysine residue at the same position (Fig 3).

\section{DISCUSSION}

Dengue fever outbreaks occur frequently in Brazil, including in MT. However, testing samples from febrile patients solely for DENV and the yellow fever virus could mean that other flaviviruses silently cocirculating in the region may go undetected. For this reason, differential diagnosis during dengue outbreaks should be performed routinely.

To the authors' knowledge, this is the first report of SLEV and DENV4 co-infections in Brazilian patients, including a DENV-1, DENV-4 and SLEV triple infection. Clinical complications were not identified at the time of sample collection. Therefore, it was not possible to determine the etiology of the acute febrile illness. DENV-3 and SLEV co-infection, accompanied by hemorrhagic manifestations without increased severity, was previously reported during a dengue fever epidemic in the city of São José do Rio Preto, SP, southeastern Brazil ${ }^{12}$.

SLEV infection may be underestimated in MT. Only patients with acute febrile illness for less than five days were included in the present study. Further studies to estimate seroprevalence in the population, as well as to identify the vector species transmitting the virus, are a matter to be addressed shortly.

One $C x$. quinquefasciatus female captured in the Bela Vista neighborhood of Cuiabá was positive for SLEV (MIR =0.29). Aedes and Culex spp. are involved in DENV and SLEV transmission, respectively ${ }^{24}$. The co-infections described here likely resulted from exposure to both infected mosquito species. However, several other mosquito species have been described as SLEV vectors.

Although SLEV has been detected in both urban and sylvatic environments of Brazil and that Amazônia and Pantanal constitute the majority of territory in Mato Grosso, the three human cases reported here were detected within a large metropolitan area, located in the Cerrado biome (Fig 1). These cases were reported during a large DENV-4 outbreak, indicating that flaviviruses besides DENV may be circulating in MT. Although under-notification is common, data from the Notifiable Diseases Information System in 2012 included 44,814 notifications of dengue fever cases in MT, 10,742 of them in Cuiabá and 3,133 in Várzea Grande, attributed to DENV-4 (96.2 \%) and DENV-1 $(3.8 \%)^{2,11}$.

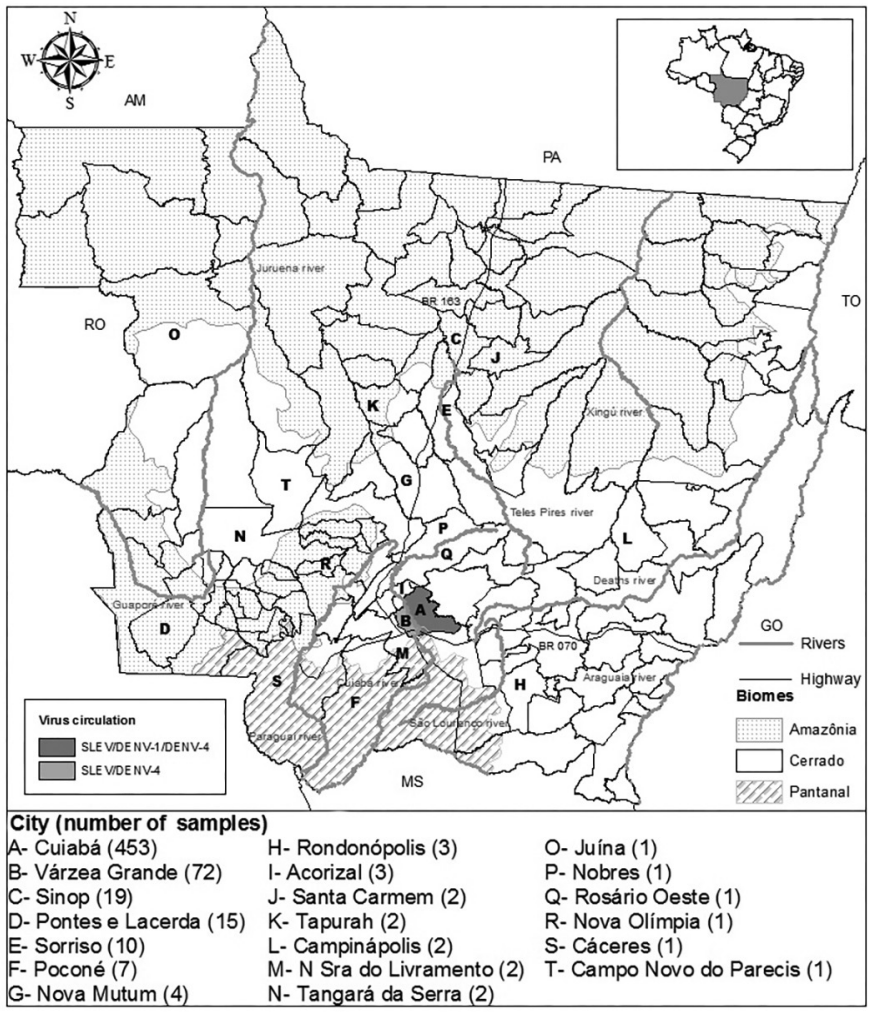

Fig 1 - Distribution of patients with acute febrile illness in the state of Mato Grosso between 2011 and 2012 tested for flaviviruses species by multiplex semi-nested RT-PCR. Cities with patients who tested positive for dengue virus (DENV) serotypes 1 and 4 and Saint Louis encephalitis virus (SLEV) are identified.

SLEV is currently classified by eight lineages, 15 subtypes, based on envelope gene or genome sequences. These lineages correlate with the geographical distribution of the virus. The Brazilian strains reported so far belong to SLEV genotypes II, III, V, and VIII (subtypes A and $\mathrm{B})$, with $\mathrm{V}$ and VIII being the most prevalent in the Amazon region ${ }^{18}$.

Phylogenetic analysis shows that SLEV identified in the present study within humans (SLEV_BR/MT-CbaH364/2012) and mosquitoes (SLEV_BR/MT-CbaAr499/2013) belong to genotype V-A, closely related to isolates from animals in the Amazon region, in the state of Pará (Fig. 2). Previously, genotype VIII-B was isolated from birds in the Amazon in MT in $1974^{18}$.

The phylogenetic tree, constructed with strains belonging to the eight lineages of SLEV, demonstrates a common ancestry between the human SLEV_BR/MT-CbaH364/2012, mosquito SLEV_BR/MTCbaAr499/2013 and SLEV isolates from PA and Argentina belonging to genotype V. The MT SLEV samples clustered with a bootstrap value of $98 \%$, originating a clade in genotype $\mathrm{V}$. They also indicated a homology 
HEINEN, L.B.S.; ZUCHI, N.; SERRA, O.P.; CARDOSO, B.F.; GONDIM, B.H.F.; SANTOS, M.A.M.; SOUTO, F.J.D.; PAULA, D.A.J.; DUTRA, V. \& DEZENGRINI-SLHESSARENKO, R. - Saint Louis encephalitis virus in Mato Grosso, Central-Western Brazil. Rev. Inst. Med. Trop. Sao Paulo, 57(3): 215-20, 2015.

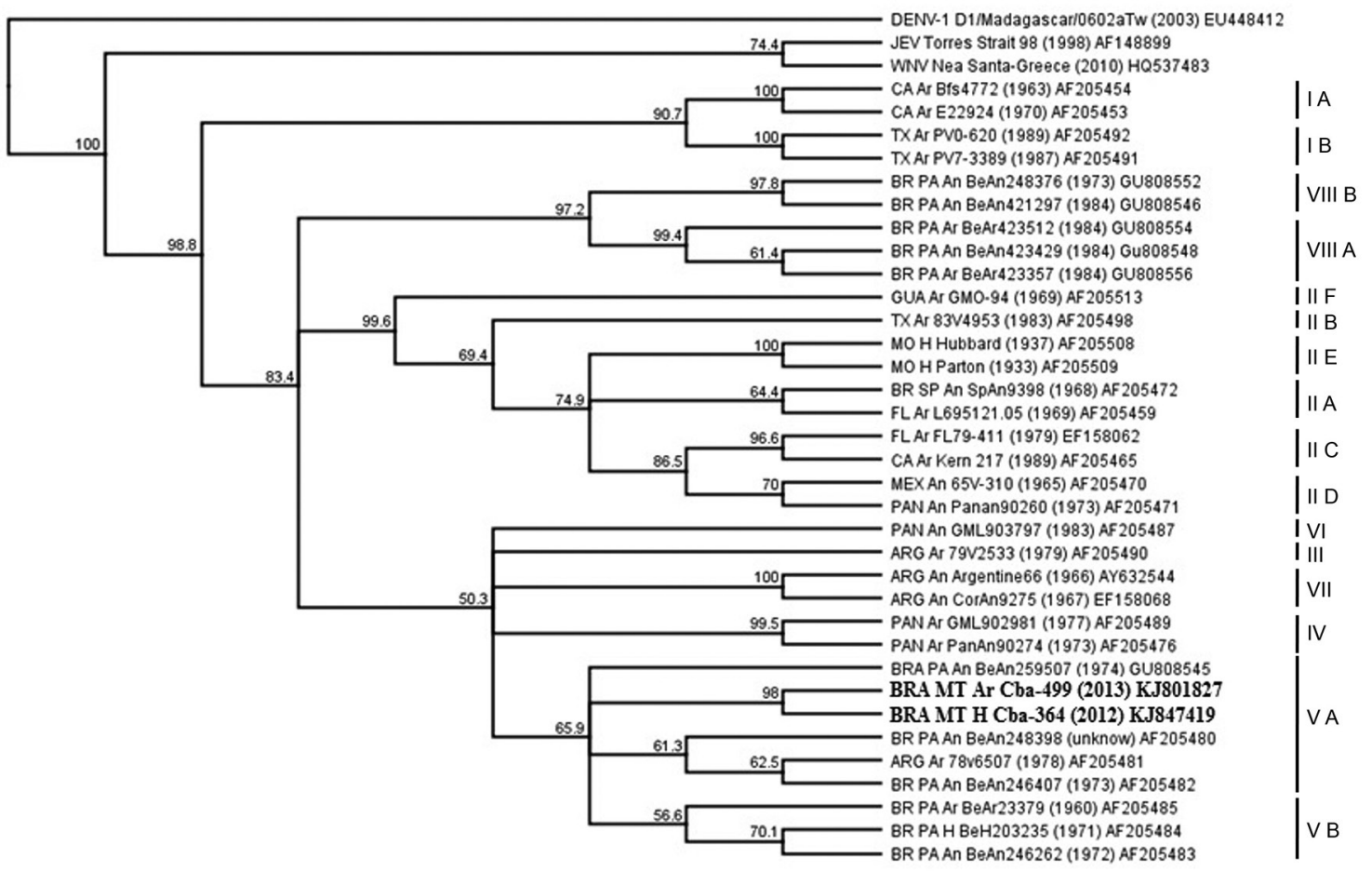

Fig 2 - Phylogenetic tree of envelope gene sequences from SLEV_BR/MT-CbaH364/2012, SLEV_BR/MT-CbaAr499/2013 and Saint Louis encephalitis virus (SLEV) genotypes deposited at GenBank (NCBI), using the neighbor-joining method, Tamura-Nei distance model and 1,000 bootstrap replicates. Outgroups included Japanese encephalitis virus (JEV), West Nile virus (WNV), and dengue virus 1 (DENV-1).

of $99 \%$ in the nucleotide sequence, suggesting that the same virus may be circulating in vectors and hosts. Although in the present study (Fig. 2 ), the cluster within lineage $\mathrm{V}$ is not supported by a high bootstrap value $(65.9 \%)$, similar results were described by others when analyzing partial envelope sequences of SLEV strains belonging to the same lineage ${ }^{10,23}$. The distance between the isolates in the phylogenetic tree belonging to lineage $\mathrm{V}$ ranged from $0.008 \%$ between the two samples from MT, to $0.060 \%$ among the BeAn288398 and BeAn203235 strains, from genotypes VA and VB, respectively.

The SLEV samples circulating in MT demonstrated a greater similarity to the BRA PA BeAn259507 isolate. This isolate belongs to genotype V-A, obtained from domestic birds in Altamira, PA. SLEV strains obtained from animals in Belém (BR PA An BeAn248398, BR PA An BeAn246407 and BRA PA An BeAn259507) and from Culex spp. in Argentina (ARG Ar 78v6507) are allocated in the same branch as they belong to the same genotype.

Although SLEV circulates between arthropod vectors, mammalian and avian hosts, isolates of the virus generally do not exhibit a high level of genetic diversity; indeed, the most diverse isolates have a $10.1 \%$ nucleotide divergence and, strains within each lineage show less than $5.5 \%$ nucleotide divergence ${ }^{10}$. In this regard, the sequences included in the study from genotypes VA and VB indicate nucleotide similarity between 96.1 and $99 \%$.

The most prevalent genotypes in Brazil are V and VIII, existing throughout the Amazon basin, mainly in $\mathrm{PA}^{18}$. Lineage $\mathrm{V}$ is composed of
Central and South American strains and some North American isolates from California and West Texas ${ }^{10}$. Genotype V-A, dispersed throughout the Americas, was already reported in Brazil, Argentina, Peru and Trinidad \& Tobago in vertebrate hosts and arthropod vectors. In Brazil, this genotype has been detected in different cities of PA and the state of Rondônia. Genotype V-B was only reported in PA ${ }^{18}$. Genotype VIII subtypes A and B are frequent in the Brazilian Amazon and, genotype VIII-B was already isolated from Amazon region birds of MT in 1974 and from one horse with a neurological disease from MG in $2013^{18,20}$.

The analysis of the envelope amino acid sequences revealed a high homology between the human SLEV_BR/MT-CbaH364/2012 and the mosquito SLEV_BR/MT-CbaAr499/2013. None of the variations described for other lineages in positions that were present in the analyzed envelope amino acid partial sequence were observed in the MT samples ${ }^{10}$. The leucine residue at position 96 in the human SLEV_BR/ MT-CbaH364/2012, whereas all the other studied amino acid sequences from genotypes II, V and VII presented a proline residue, has already been described in the human SLEV sample from São José do Rio Preto, SP ${ }^{23}$. Additionally, the SLEV_BR/MT-CbaAr499/2013 obtained from mosquitoes showed an asparagine at position 45, whereas all the other SLEV strains analyzed in the present study, including the human SLEV_BR/MT-CbaH364/2012, have a lysine residue at the same position (Fig. 3). The homology between the human and arthropod SLEV samples, identified in MT, indicates that the same virus is perhaps circulating in both vector and vertebrate host populations.

Birds are believed to carry SLEV to different regions, and may be 
HEINEN, L.B.S.; ZUCHI, N.; SERRA, O.P.; CARDOSO, B.F.; GONDIM, B.H.F.; SANTOS, M.A.M.; SOUTO, F.J.D.; PAULA, D.A.J.; DUTRA, V. \& DEZENGRINI-SLHESSARENKO, R. - Saint Louis encephalitis virus in Mato Grosso, Central-Western Brazil. Rev. Inst. Med. Trop. Sao Paulo, 57(3): 215-20, 2015.
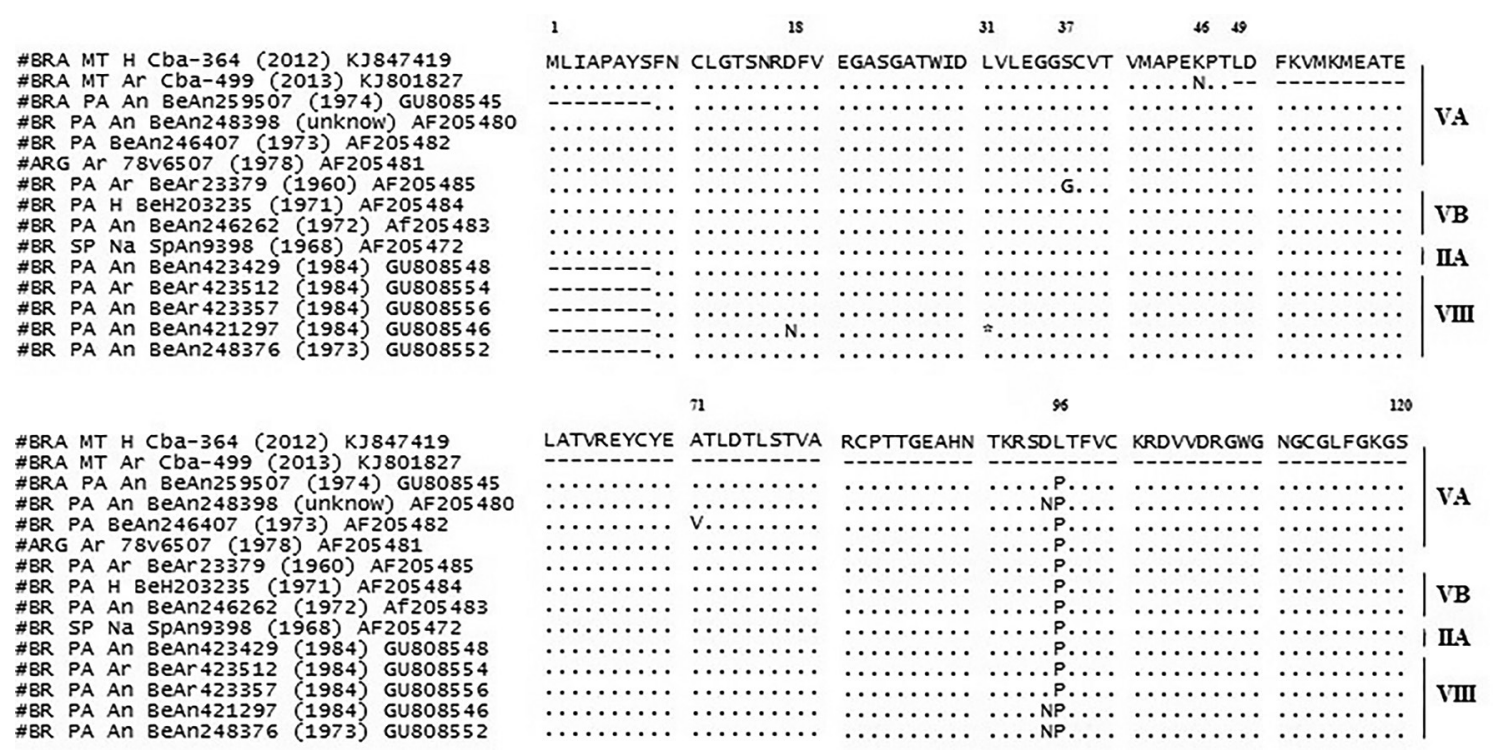

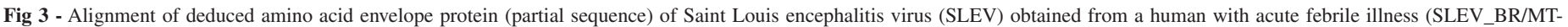

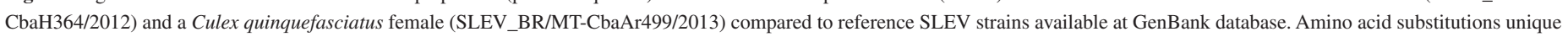
to the samples from Mato Grosso are in bold.

responsible for introducing SLEV V-A in MT, due to migratory routes from the Amazon to Pantanal. Culex mosquitoes are abundant in MT, and most likely maintain viral transmission between birds as well as sporadic transmission to horses and humans.

SLEV infections in humans may occur sporadically in MT and be more frequent than observed in this study, conducted only with patients who sought medical care during a dengue outbreak. The absence of routine differential diagnosis may contribute to the lack of previous reports. Therefore, these findings indicate the necessity for broad-spectrum clinical-epidemiological investigations during dengue outbreaks. Active surveillance of arboviral circulation should be routinely performed in MT in the imminence of introduction or reintroduction of these viruses. Additional studies involving other animal species, birds and vector mosquitoes are necessary to comprehend the epidemiological cycle and magnitude of SLEV circulation in MT.

\section{RESUMO}

\section{Vírus da encefalite de Saint Louis em Mato Grosso, Centro-Oeste, Brasil}

O vírus da dengue (DENV), frequentemente envolvido em epidemias de grande proporção, e o vírus da febre amarela (YFV), responsável por surtos silvestres esporádicos, são considerados os flavivírus circulantes mais importantes no Brasil. Por este motivo, o diagnóstico laboratorial de doença febril aguda indiferenciada durante períodos epidêmicos é frequentemente direcionado para dengue e febre amarela no país, dificultando a detecção de outros arbovírus possivelmente circulantes, incluindo o vírus da encefalite de Saint Louis (SLEV), que é amplamente disperso nas Américas. O objetivo deste estudo foi investigar molecularmente a presença de 11 flavivírus no soro de 604 pacientes durante grande epidemia de dengue no estado de Mato Grosso (MT), Centro-Oeste do Brasil, entre 20112012. Concomitantemente, 3.433 fêmeas de Culex spp. capturadas com aspirador de Nasci na cidade de Cuiabá, MT e alocadas em 409 pools com 1-10 mosquitos em 2013 foram testadas por multiplex seminested RT-PCR para os mesmos flavivírus. O SLEV foi detectado em três pacientes co-infectados com o DENV-4 das cidades de Cuiabá e Várzea Grande, MT. Um dos pacientes apresentava tripla co-infecção com DENV-1. Nenhum paciente referiu histórico recente de viagem ou acesso a áreas rurais/silvestres. Um pool contendo uma fêmea de Culex quinquefasciatus foi positivo para o SLEV, apresentando taxa de infecção mínima (MIR) de 0,29 por 1000 espécimes desta espécie. A análise filogenética indica que ambas as amostras formam um cluster com isolados do genótipo V-A do SLEV obtidos de animais na região amazônica do estado do Pará. Este é o primeiro relato de identificação molecular do SLEV no MT.

\section{ACKNOWLEDGMENTS}

The authors thank Ana E. Viniski, Sumako U. Kinoshita (LACEN/ MT, SES, Cuiabá), Liliana V. A. Correa, (FM, UFMT, Cuiabá) for their assistance. In addition, they thank Fernanda C. Pereira, a medical graduate student, for her scientific training, Roberta V. M. Bronzoni (UFMT Sinop) for providing RNA of the SLEV positive control and Mauricio L. Nogueira (FAMERP) for training and discussion of the results.

\section{FINANCIAL SUPPORT}

This study was supported by the National Council for Scientific and Technological Development (CNPq; grant 472890/2011-5). NZ, LBSH, OPS and BFC were recipients of the Coordination for the Improvement of Higher Education Personnel (CAPES) scholarships; FCP and BHFG were recipients of the UFMT scientific initiation scholarships. 
HEINEN, L.B.S.; ZUCHI, N.; SERRA, O.P.; CARDOSO, B.F.; GONDIM, B.H.F.; SANTOS, M.A.M.; SOUTO, F.J.D.; PAULA, D.A.J.; DUTRA, V. \& DEZENGRINI-SLHESSARENKO, R. - Saint Louis encephalitis virus in Mato Grosso, Central-Western Brazil. Rev. Inst. Med. Trop. Sao Paulo, 57(3): 215-20, 2015.

\section{REFERENCES}

1. Bronzoni RVDM, Baleotti FG, Nogueira MRR, Nunes M, Figueiredo LTM. Duplex reverse transcription-PCR followed by nested PCR assays for detection and identification of Brazilian alphaviruses and flaviviruses. J Clin Microbiol. 2005;43:696-702.

2. Capelassi C. Saúde divulga dados da Dengue de 2013 e o fechamento de 2012. [Internet]. Cuiabá (Brazil): Secretaria Estadual de Saúde do Mato Grosso. [cited 2013 Jan 16]. Available from: www.saude.mt.gov.br/noticia/3291

3. Forattini OP. Culicidologia médica. São Paulo: EDUSP; 1996. v.1, p. 531.

4. Forattini OP. Culicidologia médica. São Paulo: EDUSP; 2002. v. 2, p.548.

5. Fulop L, Barrett AD, Phillpotts R, Martin K, Leslie D, Titball RW. Rapid identification of flaviviruses based on conserved NS5 gene sequences. J Virol Methods. $1993 ; 44: 179-88$

6. Kramer LD, Chandler LJ. Phylogenetic analysis of the envelope gene of St. Louis encephalitis virus. Arch. Virol. 2001;146:2341-55.

7. Kuhn R. Flaviviruses. In: Acheson NH, editor. Fundamentals of molecular Virology. New York: John Wiley \& Sons; 2007. p. 181-90.

8. Lopes OS, Sacchetta LA, Coimbra TL, Pereira LE. Isolation of St. Louis encephalitis virus in South Brazil. Am J Trop Med Hyg. 1979;28:583-5.

9. Maia FGM, Chávez JH, Souza WM, Romeiro MF, Castro Jorge LA, Fonseca BAL, et al. Infection with Saint Louis encephalitis virus in the city of Ribeirão Preto, Brazil: report of one case. Int J Infect Dis. 2014;269:96-7.

10. May FJ, Li L, Zhang S, Guzman H, Beasley DWC, Tesh RB, et al. Genetic variation of St. Louis encephalitis virus. J Gen Virol. 2008;89:1901-10.

11. Ministério da Saúde. Balanço Dengue I Janeiro a abril 2012. [Internet]. Brasilia: Ministry Health of Brazil; 2012. Available from: http://www.slideshare.net/MinSaude/ balano-dengue-i-jan-a-abr-2012

12. Mondini A, Bronzoni RVDM, Cardeal ILS, Santos TMILS, Lázaro E, Nunes SHP, $e$ al. Simultaneous infection by DENV-3 and SLEV in Brazil. J Clin Virol. 2007;40:84-6.

13. Mondini A, Cardeal ILS, Lázaro E, Nunes SH, Moreira CC, Rahal P, et al. Saint Louis encephalitis virus, Brazil. Emerg Infect Dis. 2007;13:176-8.

14. Ometto T, Durigon EL, de Araujo J, Aprelon R, de Aguiar DM, Cavalcante GT, et al. West Nile virus surveillance, Brazil, 2008-2010. Trans R Soc Trop Med Hyg. 2013;107:723-30.

15. Pauvolid-Corrêa A, Tavares FN, Costa EV, Burlandy FM, Murta M, Pellegrin AO, et al. Serologic evidence of the recent circulation of Saint Louis encephalitis virus and high prevalence of equine encephalitis viruses in horses in the Nhecolândia sub-region in South Pantanal, Central-West Brazil. Mem Inst Oswaldo Cruz. 2010;105:829-33.
16. Pinheiro FP, LeDuc JW, Travassos da Rosa AP, Leite OF. Isolation of St. Louis encephalitis virus from a patient in Belém, Brazil. Am J Trop Med Hyg. 1981;30:1458 .

17. Rodrigues SG, Oliva OP, Araujo FAA, Martins LC, Chiang JD, Henriques DF, et al. Epidemiology of Saint Louis encephalitis virus in the Brazilian Amazon region and in the State of Mato Grosso do Sul, Brazil: elevated prevalence of antibodies in horses. Rev Pan-Amazônica Saúde. 2010;1:81-6.

18. Rodrigues SG, Nunes MRT, Casseb SMM, Prazeres ASC, Rodrigues DSG, Silva MO, et al. Molecular epidemiology of Saint Louis encephalitis virus in the Brazilian Amazon: genetic divergence and dispersal. J Gen Virol. 2010;91:2420-7.

19. Rocco IM, Santos CLS, Bisordi I, Petrella SMCN, Pereira LE, Souza RP, et al. St. Louis encephalitis virus: first isolation from a human in São Paulo State, Brazil. Rev Inst Med Trop Sao Paulo. 2005;47:281-5.

20. Rosa R, Costa EA, Marques RE, Oliveira TS, Furtini R, Bomfim MRQ, et al. Isolation of Saint Louis encephalitis virus from a horse with neurological disease in Brazil. PLOS Negl Trop Dis. 2013;7:e2537

21. Silva JR. Pesquisa de infecções por flavivírus da encefalite de Saint Louis, Rocio e Oeste do Nilo em cavalos, por inquérito sorológico e isolamento viral. [Dissertation]. São Paulo: Universidade de São Paulo; 2010.

22. Smith JL, Fonseca DM. Rapid assays for identification of members of the Culex (Culex) pipiens complex, their hybrids and other sibling species (Diptera Culicidae). Am J Trop Med Hyg. 2004;70:339-45.

23. Terzian ACB, Mondini A, Bronzoni RVM, Drumond BP, Ferro BP, Cabrera EMS, et al. Detection of Saint Louis encephalitis virus in dengue-suspected cases during a dengue 3 outbreak. Vector Borne Zoonotic Dis. 2011;11:291-300.

24. Vasconcelos PFC, Travassos da Rosa APA, Pinheiro FP, Shope RE. Arboviruses pathogenic for man in Brazil. In: Travassos da Rosa APA, Vasconcelos PFC, Travassos da Rosa JFS, editors. An overview of arbovirology in Brazil and neighbouring Countries. Belém: Instituto Evandro Chagas; 1998. p. 72-99.

25. Vasconcelos PFC, Travassos da Rosa JFS, Travassos da Rosa APA, Degallier N Epidemiologia das encefalites por arbovírus na Amazônia Brasileira. Rev Inst Med Trop Sao Paulo. 1991;33:465-76.

26. Webster LT, Fite GL. A virus encountered in the study of material from cases of encephalitis in the St. Louis and Kansas city epidemics of 1933. Science. 1933;78(2019):463-5.

Received: 15 June 2014

Accepted: 26 August 2014 